УДК 78.07:37-047.22

DOI: 10.37026/2520-6427-2021-106-2-160-164

\author{
Олена НИКОН, \\ доцент кафедри естрадної музики \\ Рівненського державного \\ гуманітарного університету, \\ м. Рівне, Украӥна \\ ORCID: 0000-0002-0844-6467 \\ e-mail: olenanykon@ukr.net \\ Марія ОСТАПЧУК, \\ дочент кафедри гри \\ на музичних інструментах \\ Рівненського державного \\ гуманітарного університету, \\ м. Рівне, Україна \\ ORCID: 0000-0002-8800-7025 \\ e-mail:maria.budz.ostapchuk@gmail.com
}

\title{
ПЕДАГОГІЧНІ АСПЕКТИ ФОРМУВАННЯ ФАХОВИХ КОМПЕТЕНТНОСТЕЙ ЗДОБУВАЧІВ ВИЩОЇ ОСВІТИ У КОНЦЕРТМЕЙСТЕРСЬКОМУ КЛАСІ
}

\begin{abstract}
Анотація. У статті розглядаються педагогічні аспекти формування професійних компетентностей концертмейстера у процесі вивчення дисциилліни «Концертмейстерський клас» здобувачами вищоі освіти за освітньою програмою «Музичне мистеитво. Фортепіано».

Проаналізована кониертмейстерська діяльність як найбільш поширена та доступна форма навчальноі та виконавської роботи піаніста. Підкреслено, шчо у сучасних наукових та методичних виданнях питання підготовки кониертмейстерів у закладах вищої освіти, зокрема викладання концертмейстерського класу, висвітлені недостатньо. Окреслено специфіку роботи концертмейстера, щьо полягає у розумінні ним ролі акомпанементу для створення високохудожнього музичного образу спільно із солістом або з групою виконавиів. Схарактеризовано проиес формування його професійних компетентностей, визначено завдання
\end{abstract}

навчальної дисиипліни «Кониертмейстерський клас», щзо є обов 'язковим компонентом освітньо-професійної програми «Музичне мистецтво. Фортепіано».

У публікації окреслюється основа робочої програми означеної дисциилліни, щзо базується на концепиії концертмейстера як піаніста, який не тільки акомпанує, а й здатний праиюювати із солістом, розучувати з ним новий репертуар та знаходити способи вирішення його виконавських проблем. У статті розглядаються особливості взаємодії та основні елементи роботи концертмейстера із солістами під час вивчення аналізованої дисиипліни: етапи роботи над акомпанементом, удосконалення навичок читання нот із листа, транспонування музичного матеріалу та ансамблевого музикування.

Ключові слова: кониертмейстер, акомпанемент, кониертмейстерський клас, читання з листа, транспонування, ансамблеве виконавство.

\author{
Olena NYKON, \\ Associate Professor \\ of the Variety Music Chair, \\ Rivne State University of Humanities, \\ Rivne, Ukraine \\ ORCID: 0000-0002-0844-6467 \\ e-mail: olenanykon@ukr.net
}

\author{
Maria OSTAPCHUK, \\ Associate Professor of the Chair \\ of Playing the musical instruments, \\ Rivne State University of Humanities, \\ Rivne, Ukraine \\ ORCID: 0000-0002-8800-7025 \\ e-mail: maria.budz.ostapchuk@gmail.com
}




\section{PEDAGOGICAL ASPECTS \\ FORMATION OF PROFESSIONAL COMPETENCIES OF HIGHER EDUCATION STUDENTS IN THE CONCERT MASTER CLASS}

\begin{abstract}
The article reveals pedagogical aspects of formation professional competences of accompanists in the process of studying the education program «Musical Art. Piano».

The accompanist activity is the most spread and available from of educational and performing work of a pianist. Modern scientific and methodical editions don't highlight the question of teaching accompanists in Higher educational establishments, in particular the teaching of accompanist class is not sufficient. The specific features of accompanist work are in his understanding the role of accompaniment for creating highly artistic musical image together with a soloist or a group of performers. The formation of his professional competence is the task of the academic discipline "The Accompanist class». It is one of the obligatory components of educational professional program «Musical Art. Piano».

The concept of accompanist as a pianist does not only include his accompaniment but he is also able to work with a soloist, to learn a new repertoire with him and to find the ways of solving his performing problems. This concept must be put into the foundation of the syllabus of the given discipline.
\end{abstract}

The article reveals the peculiarities of interaction and the main elements of accompanist work with soloists during the process of studying this discipline: stages of work on accompaniment, improving skills of reading notes from the music sheets, transposition of musical material and ensemble music making.

Conclusions and prospects of further research. The syllabus of the educational discipline "The accompanist class" forms in students-pianists skills and practical knowledge necessary for professional activity: the work with soloists on learning the repertoire, accompanying soloists, ensemble, choir, reading, from the music sheet, transposition of a musical material, simplification of texture elements of the accompaniments and its creative transformation. The program demands of the discipline are also aimed at the upbringing in accompanist personal qualities - creative will, emotional receptivity, artistic taste. The effective of mastering necessary skills by the competitors for the higher education is provided by the successive studying of the systematized repertoire and practical experience of concert-performing work.

Key words: accompanist, accompaniment, accompanist class, reading from the music sheet, transposition, ensemble performance.

Постановка проблеми. Упровадження європейських стандартів в освітній процес вимагає нових підходів до викладання дисциплін у закладах вищої освіти України. Основою робочих програм стає формування загальних та спеціальних компетентностей майбутнього фахівця, які визначені освітньо-професійною програмою відповідної спеціальності. Науковці та викладачі мистецьких закладів активізують пошуки нових форм і методів роботи, спрямовані на вдоско- налення фахової підготовки здобувачів вищої освіти спеціальності 025 «Музичне мистецтво». За цієї умови актуалізується проблема формування мотивації, професійного розвитку і саморозвитку майбутнього фахівця.

Концертмейстерська діяльність є найбільш доступною та поширеною формою навчальної та виконавської роботи піаніста як у закладі освіти, так і на професійній сцені. Підготовка фахівців, які отримують цю кваліфікацію, здійснюється у закладах вищої освіти за освітньо-професійною програмою «Музичне мистецтво. Фортепіано». Компетентнісний підхід за цієї умови є пріоритетним напрямом розробки програм фахової підготовки, зокрема навчальної дисципліни «Концертмейстерський клас». Специфіка її викладання передбачає формування у студентів навичок ансамблевого музикування, вивчення із солістами нового репертуару, читання з листа та транспонування музичного матеріалу.

Національне агентство із забезпечення якості вищої освіти рекомендує періодично переглядати освітні програми з урахуванням пропозицій стейкхолдерів (роботодавців, випускників, академічної спільноти). Зв'язок закладу освіти з роботодавцями спрямовує викладачів на вдосконалення робочих програм навчальних дисциплін, що передбачають формування загальних та спеціальних компетентностей та програмних результатів навчання з урахуванням вимог майбутньої професійної діяльності. У сучасних наукових та методичних працях проблеми викладання концертмейстерського класу та особливості професії концертмейстера висвітлені недостатньо. Передусім ці реалії обумовлюють актуальність означеної теми та безпосередньо нашу зацікавленість нею.

Аналіз наукових досліджень і публікацій. Питанню впровадження компетентнісного підходу в розробку програм підготовки фахівців у галузі музичного мистецтва присвячено чимало праць учених. Вивчення проблем методик викладання фахових дисциплін навчання концертмейстерів у закладах вищої освіти, їх виконавської діяльності, становлення та розвитку цієї професії в історичному аспекті є предметом досліджень Т. Молчанової, А. Філяєвої, Е. Афанасьєвої та багатьох інших викладачів, науковців та провідних концертмейстерів закладів вищої освіти. Так, у навчальному посібнику Т. Молчанової «Мистецтво піаніста-концертмейстера» комплексно розглянуто та систематизовано необхідні знання та навички, висвітлено проблеми виховання концертмейстера та методи роботи, необхідні для підготовки фахівців у закладах вищої освіти.

Питання професійної діяльності та методики роботи концертмейстера із солістами також $є$ предметом вивчення викладачів кафедри концертмейстерства Львівської національної академії ім. М. В. Лисенка, зокрема Л. Ніколаєвої, М. Макари, Н. Бабинець, Я. Матюхи, 
Т. Молчанової. За результатами досліджень видана значна кількість методичних праць, що стали практичними посібниками у вихованні майбутніх концертмейстерів. Методичні принципи, якими повинен керуватися піаніст-концертмейстер у роботі з естрадними вокалістами, досліджують і провідні концертмейстери Київського національного інституту культури та мистецтв (А. Хлопотова, О. Опанасенко та інші). Дослідники вивчають особливості його роботи з естрадними виконавцями, зокрема підкреслюють необхідність формування певних педагогічних навичок та вмінь здійснювати власне аранжування твору та імпровізувати в ньому. «Крім того, ця діяльність передбачає наявність високого рівня виконавства з боку акомпаніатора, який повинен доповнюватись педагогічними навичками, що виявлятимуться у психологічній підтримці вокаліста, вмінні відпрацьовувати проблемні елементи» (Хлопова, Опанасенко, Олейніков, 2017, с.108).

Зазначене вище свідчить про неабияке зацікавлення науковою та освітянською спільнотою вивченням запропонованої теми. Питання специфіки співтворчості вокаліста і піаніста також є предметом дослідженнь Л. Несмашної, С. Сарбі, В. Бокоч. На думку вчених, «сутність співтворчості є взаємодією двох творчих особистостей, кожна з яких у процесі спільної професійної діяльності реалізує свою творчу активність, розкриває індивідуальні можливості свого дарування, а також прагне до злиття, взаємопроникнення творчих задумів іншого партнера 3 метою досягнення ансамблю на високому рівні професійної майстерності, формування індивідуального виконавського стилю дуету «співак-концертмейстер», створення єдиної художньої інтерпретації музичного твору як оригінального продукту особистісного і соціального значення» (Несмашна, Сарбі, Бокоч, 2017, с.118).

Т. Молчанова у монографії «3 історії ансамблевого музикування» також простежує особливості становлення професії піаніста-концертмейстера у європейській та українській музичній культурі, а специфіку роботи концертмейстера зі студентами-музикантами диригентських спеціалізацій у закладах вищої освіти аналізує Е. Афанасьєва. Однак, незважаючи на значну кількість праць у цьому напрямку, варто зазначити, що педагогічні аспекти формування професійних компетентностей піаніста під час вивчення дисципліни «Концертмейстерський клас» вивчені недостатньо.

У зв'язку з цим метою статті $\epsilon$ визначення педагогічних аспектів формування фахових компетентностей у здобувачів вищої освіти під час вивчення дисципліни «Концертмейстерський клас».

Виклад основного матеріалу дослідження. Поняття «концертмейстер» має досить широке значення. Це перший скрипаль оркестру; музикант, який очолює кожну із груп симфонічного оркестру; піаніст-акомпаніатор, котрий працює з виконавцями під час вивчення репертуару та акомпанує їм у концертах, бере участь в освітньому процесі. Суб' єктом нашого дослідження і $є$ піаніст-акомпаніатор, який окрім знання особливостей власної професії повинен мати й педагогічні навички (Молчанова, 2001). Специфіка роботи концертмейстера насамперед полягає у розумінні ним ролі акомпанементу для створення високохудожнього музичного образу твору спільно із солістом або з групою виконавців. Колективне виконання зумовлює виховання у нього досконалої індивідуальної техніки гри на інструменті та розвинутого почуття ансамблю. Ця професія «вимагає від піаніста багатосторонніх знань і вмінь із курсів гармонії, сольфеджіо, історії музики, вокальної та хорової літератури, педагогіки в їх взаємозв'язках» (Афанасьєва, 2017, c. 45). Формування його професійних компетентностей завдання навчальної дисципліни «Концертмейстерський клас», яка є одним з основних компонентів освітньо-професійної програми «Музичне мистецтво. Фортепіано».

Як зазначалося вище, програми навчання переглядаються стейкхолдерами. Роботодавці та керівники баз практики в цілому це схвалюють, пропонуючи водночас удосконалити у робочих програмах завдання, які формують навички, необхідні для майбутньої професійної діяльності випускників, приміром, читання нот із листа, транспонування музичних творів, а також уміння працювати з солістом над вирішенням його виконавських проблем. Означені навчальні завдання введені до робочої програми дисципліни, однак із тих чи інших причин їм не приділяється належної уваги. На нашу думку, необхідно врахувати ці питання до вимог поточного та семестрового контролю, що підвищить мотивацію студентів і викладачів до їх виконання. Викладач може заперечити, мовляв, не вистачає навчального часу для читання 3 листа або транспонування творів, зокрема для імпровізації, проте буває, що на занятті з концертмейстерського класу він працює зі студентом над програмою із спецінструменту, тому що в навантаженні у нього наявні дві дисципліни. Варто зазначити, що не у всіх закладах вищої освіти кафедра концертмейстерства є окремим структурним підрозділом, як у Львівській національній музичній академії ім. М. В. Лисенка. Цей факт негативно впливає на статус фаху, фундаментальність підготовки студентів, необхідність науково-методичного обгрунтування методів навчання та ефективність концертно-виконавської роботи.

В основі робочої програми навчальної дисципліни «Концертмейстерський клас» повинна бути концепція концертмейстера як піаніста, який не тільки акомпанує, а й здатний працювати із солістом, розучувати 3 ним новий репертуар та знаходити способи вирішення його виконавських проблем. Вочевидь, до змісту програми необхідно ввести теми з вивчення літературних джерел вокальної музики, виконавських особливостей роботи з вокалістом та інструменталістом, а також ознайомлення з історією становлення і розвитку професії. Ці завдання допоможе вирішити навчальна дисципліна «Методика роботи у концертмейстерському класі».

Отож проаналізуємо педагогічні аспекти підготовки концертмейстера. Вивчення ним акомпанементу до вокального або інструментального твору відбувається поетапно. Перший етап передбачає ознайомлення виконавців із твором загалом, його фактурою, змістом, образними характеристиками, партією соліста. У роботі над вокальним акомпанементом важливо також знати особливості літературного тексту. Неабиякого значення на цьому етапі набувають навички читання з листа нотного тексту. На думку Т. Молчанової, «для професійної діяльності концертмейстера цей навик $€$ надзвичайно важливим і навряд чи в однаковій мірі 
доступний усім через різний професійний рівень. Однак це вміння неоціненне у навчальній роботі та визначає темп розвитку як учня, так і студента» (2001, с. 38). Авторка окреслює низку завдань під час читання з листа: швидке охоплення всієї фортепіанної фактури; вміння відібрати в ній головне за короткий проміжок часу (після зорового огляду твору); оволодіння нотним текстом так, щоб вільно грати по нотах.

Основною умовою успішного оволодіння майбутніми концертмейстерами означеними вміннями $є$ достатній рівень технічної піаністичної бази (рухливість пальців, уміння диференціювати звучання мелодії та гармонії в акомпанементі). Також важливим $є$ вміння обрати потрібну аплікатуру, систематичність та послідовність самостійної роботи над розвитком навичок та прийомів миттєвої орієнтації у фактурі твору, зокрема у мелодії, гармонії, метроритмі, темпі. Досить часто на заваді у розвитку вміння швидко читати нотний текст стає психологічний бар'єр. Проблема його подолання стає важливим завданням початкового етапу занять із концертмейстерського класу.

Завданням другого етапу роботи над акомпанементом $є$ технічне оволодіння нотним текстом, репетиційна робота із солістом, створення переконливої художньої інтерпретації у творчій взаємодії. Особливість вивчення супроводу до вокального твору полягає в тому, що його образ розкривається через музику та літературний текст. Емоційно-виразова декламація допоможе зрозуміти його драматургію, темпоритм, динаміку, визначити кульмінацію. Концертмейстер також повинен знати вокальну партію і навчитися 111 відтворювати. Жанр, характер твору, тип фактури, засоби музичної виразності (лад, гармонія, артикуляція, темп та інші) визначають художні та технічні завдання його інтерпретації.

Сольні фрагменти акомпанементу (вступ, інтермедія, кода) відіграють надзвичайно важливу роль, адже виконуючи вступ, концертмейстер обумовлює характер твору, встановлює його темп. В інтерлюдії акомпанемент доповнює вокальну партію та виконує роль диригента ансамблю, підтримує темпоритм твору й цілісність форми.

Отже, основними завданнями репетиційного етапу роботи з вокалістом є: досягнення спільної темпоритмічної організації виконання твору (загального темпу, темпу частин, тривалості частин, витриманих нот); відпрацювання динамічних співвідношень звукових рівнів сольної партії та акомпанементу; визначення загального динамічного плану інтерпретації, досягнення природності та гнучкості акомпанементу (виразності мелодії, підголосків, лінії басу на фоні гармонії, а також уміння працювати із солістом над вокальною партією). Вокаліст повинен добре знати діапазони голосів, найбільш притаманні для них теситури, орієнтуватися в основних елементах вокальної техніки, особливостях дихання, артикуляції, володіти комплексом елементарних технічних вправ для розспівування соліста. Поетапна спільна робота концертмейстера $з$ вокалістом $\epsilon$ запорукою швидкого вивчення твору та створення справжнього творчого ансамблю виконавців.

Професійно необхідною навичкою, яку повинні набути студенти під час вивчення дисципліни
«Концертмейстерський клас», $є$ транспонування творів в іншу тональність. «Це найбільш стосується роботи 3 вокалістами, оскільки за відсутності існування романсу у необхідній для співака тональності концертмейстер повинен зробити відповідне транспонування» (Молчанова, 2001, с. 46). Означений вид діяльності вимагає від концертмейстера максимальної слухової активності та концентрації уваги. Основною умовою транспонування є відчуття нової тональності. Важливо зрозуміти, що під час транспонування на будь-який інтервал, крім октави, змінюється тональність, проте ладові властивості транспонованого матеріалу (чергування ладових ступенів, побудова акордів, інтервальні співвідношення у мелодіях, акордах тощо) завжди зберігаються (Молчанова, 2001).

Передумовою злагодженого ансамблевого виконання інструментальних творів із фортепіано є розуміння акомпаніатором технічних та художньо-виражальних можливостей інструментів - духових, струнних, ударних, народних тощо, а також ролі фортепіанного супроводу у створенні солістом музичного образу. Так, концертмейстер, виконуючи інструментальний акомпанемент, повинен враховувати тембр, динамічний діапазон, технічну можливість інструменту, що виконує соло. Повноцінне відчуття ансамблю виникає на основі чіткої слухової орієнтації піаніста, вміння чути найменші нюанси партії соліста і миттєвої реакції на зміну темпу, динаміки, дихання.

Ми поділяємо думку провідних концертмейстерів та вчених, які стверджують, що «у процесі виконавської еволюції акомпанементу надзвичайно зросли вимоги до майстерності піаніста-концертмейстера, які вже не обмежуються досконалим володінням інструменту, наявністю базових ансамблевих якостей. Сучасний піаніст-концертмейстер повинен володіти багатьма знаннями, навичками, відповідним психологічним комплексом, щоб у діалозі з партнером домагатися високого художнього результату» (Несмашна, Сарбі, Бокоч, 2017, с. 147).

Висновки. Отже, робоча програма навчальної дисципліни «Концертмейстерський клас» спрямована на формування у студентів-піаністів необхідних для професійної діяльності вмінь та навичок: роботи із солістами над вивченням репертуару; акомпанування солістам, ансамблю, хору; читання з листа, транспонування музичного матеріалу; спрощення елементів фактури акомпанементу та його творче перетворення. Програмні вимоги дисципліни спрямовані на виховання у концертмейстера і особистих якостей - творчої волі, емоційної сприйнятливості, художнього смаку. Ефективність опанування здобувачами вищої освіти необхідними вміннями забезпечується послідовним вивченням систематизованого репертуару та практичним досвідом концертно-виконавської роботи.

Перспективи подальших досліджень. Серед викладачів і студентів мистецьких закладів освіти існує думка щодо другорядності ролі концертмейстера у музичній діяльності, тому сформувалася певна недоццінка занять із концертмейстерства, недостатнє методичне обгрунтування самостійної роботи студентів з означеної дисципліни. Подальше дослідження проблеми полягає у поглибленому вивченні питань ансамблевого 
музикування, удосконалення навчально-методичного забезпечення з концертмейстерського класу.

\section{СПИСОК ВИКОРИСТАНОЇ ЛІТЕРАТУРИ}

Хлопова, А. А., Опанасенко, О. О., Олейніков, С. О. (2017). Роль та специфіка акомпанементу у процесі виховання естрадних вокалістів. Актуальні аспекти сучасного українського музичного мистецтва: колективна монографія / за ред. В. В. Синельникової, А. Б. Попової. Київ: Ліра. С. 104-109.

Несмашна, Л. Ю., Сарбі, С. С., Бокоч, В. А. (2017). Концертмейстер у вокально-фортепіанному дуеті: специфіка співтворчості. Актуальні аспекти сучасного украӥнського музичного мистецтва: колективна монографія / за ред. В. В. Синельникової, А. Б. Попової. Київ: Ліра. С. 110-119.

Молчанова, Т. О. (2001). Мистецтво піаніста-концертмейстера. Львів: ДМА. 216 с.

Афанасьєва, Е. Ю. (2017). Педагогічний підхід концертмейстера в роботі з студентами-музикантами. Музичне мистецтво Украӥни: монографія / за ред. Н. М. Кречка. Київ: Ліра. С. 38-45.

УДК 78:615.86

DOI: 10.37026/2520-6427-2021-106-2-164-168

\section{REFERENCES}

Khlopova, A. A., Opanasenko, O. O., Oleinikov, S. O. (2017). Rol ta spetsyfika akompanementu u protsesi vykhovannia estradnykh vokalistiv [The role and specifics of accompaniment in the process of educating pop vocalists]. Aktualni aspekty suchasnoho ukrainskoho muzychnoho mystetstva: kolektyvna monohrafiia / za red. V. V. Synelnykovoi, A. B. Popovoi. Kyiv: Lira. S. 104-109. [in Ukrainian].

Nesmashna, L. Iu., Sarbi, S. S., Bokoch, V. A. (2017). Kontsertmeister u vokalno-fortepiannomu dueti: spetsyfika spivtvorchosti [Concertmaster in a vocal-piano duo: the specifics of co-creation]. Aktualni aspekty suchasnoho ukrainskoho muzychnoho mystetstva: kolektyvna monohrafiia / za red. V. V. Synelnykovoi, A. B. Popovoi. Kyiv: Lira. S. 110-119. [in Ukrainian].

Molchanova, T. O. (2001). Mystetstvo pianistakontsertmeistera [The art of a pianist-accompanist]. Lviv: DMA. 216 s. [in Ukrainian].

Afanasieva, E. Iu. (2017). Pedahohichnyi pidkhid kontsertmeistera $\mathrm{v}$ roboti $\mathrm{z}$ studentamy-muzykantamy [Pedagogical approach of the accompanist in work with students-musicians]. Muzychne mystetstvo Ukrainy: monohrafiia / za red. N. M. Krechka. Kyiv: Lira. S. 38-45. [in Ukrainian].

Дата надходження до редакиіï: 02.03.2021 p.

\author{
Михайло КРЕТ, \\ кандидат педагогічних наук, доцент \\ кафедри пісенно-хорової практики \\ та постановки голосу \\ Інституту мистеитв \\ Рівненського державного \\ гуманітарного університету, \\ м. Рівне, Україна \\ ORCID: 0000-0002-0052-1194 \\ e-mail:9842424@gmail.com \\ Наталія ЛЕВЧУК, \\ студентка магістратури \\ кафедри естрадної музики \\ Інституту мистеитв \\ Рівненського державного \\ гуманітарного університету, \\ м. Рівне, Украӥна \\ ORCID: 0000-0003-2479-9286 \\ e-mail:krolowanataliia@gmail.com
}

\section{МУЗИКОТЕРАПІЯ ЯК ЧИННИК ВПЛИВУ НА ПСИХОЕМОЦЙНИЙ СТАН ОСОБИСТОСТІ}

Анотація. Стаття присвячена вивченню музикотерапї як оздоровчо-розвивального підходу до покращення психоемоиійного стану особистості.

Визначено, що музикотерапія - це системне використання музики з метою лікування фізіологічних та психосоиіальних аспектів хвороби та різноманітних розладів. Доведена актуальність музики та схарактеризовані ії иүілющі властивості ще з глибокої давнини. Окреслені погляди сучасних учених на музикотерапію та ї̈ вплив на лікування і профілактику багатьох захворювань.

Доведено, шео музикотерапія позитивно впливає на становлення й розвиток гармонійної особистості через вплив на емочійно-почуттєву сферу, психофізіологічний стан. Встановлено, що зміни, які відбуваються в психічному розвитку індивідуума, можуть бути коригованими та вмотивованими музично- 